\title{
Vitis $\times$ alexanderi Prince ex Jacques (Vitaceae), the first 'American Hybrid' grapes
}

\author{
David J. Mabberley
}

\begin{abstract}
Mabberley, D.J. (National Herbarium of the Netherlands, University of Leiden, The Netherlands, and Royal Botanic Gardens Sydney, NSW 2000, Australia) 1999. Vitis $\times$ alexanderi Prince ex Jacques (Vitaceae), the first 'American Hybrid' grapes. Telopea 8(3): 377-379. The first 'American Hybrid' grapes (Vitis vinifera L. $\times$ V. labrusca L.) are to be referred to as cultivars of Vitis $\times$ alexanderi, a name first validly published in a French periodical in 1829. Attention is drawn to unlisted names (in Boronia, Embothrium, Mimosa and Petrophile) of native Australian plants also validly published in the same series.
\end{abstract}

\section{Introduction}

Most grape cultivars grown in Australia are selections from hermaphrodite forms of the Old World grapevine, Vitis vinifera L., and these include all those grown for wine here. However, a few others, such as 'Concord' and 'Catawba', are known to be crosses between $V$. vinifera and the North American skunk grape, V. labrusca L. (see Scherz \& Zimmermann 1953). Elsewhere in the Pacific, notably in Hawai'i, another such hybrid important as a commercial crop is 'Isabella' (Mabberley 1998: 94, t. 37). 'Concord' is the most important cultivar in parts of the north-eastern United States and is the basis of the grape-juice industry there (Pinney 1994).

The early crosses arose spontaneously in areas of the eastern United States where the exotic $V$. vinifera was grown near $V$. labrusca populations. One of the first to be recorded was 'Alexander', which was found before 1776 in Pennsylvania, not far from where the state's founder, William Penn (1644-1718), had planted V. vinifera in 1683 (Pinney 1994). As $V$. vinifera failed over and over again in the United States because of phylloxera and other diseases, such hybrids, with resistance from $V$. labrusca, were selected, despite the 'foxy' flavour of the berries. 'Alexander', known by 1804 as 'Alexander's or Tasker's grape' (Mabberley 1998: 143), was the basis, in Indiana in 1806, of the first North American wine industry, so esteemed locally that Thomas Jefferson could declare it 'worthy of the best Vineyards of France' (Hedrick 1908: 160-1, but see below).

In his annual nursery catalogues of the 1820s, William Prince (1766-1842) of the Linnaean Botanic Garden, Flushing, New York, was offering plants of both 'Isabella' and 'Alexander' at $37 \frac{1}{2} \not$ each. These and similar cultivars were the first 'American Hybrid' grapes, a group now taken to include other crosses involving North American species. Many of those have no V. labrusca in them but are important as phylloxeraresistant rootstocks. The early hybrids were imported to Europe and others were deliberately synthesized there ('French Hybrids') in the battle to re-establish French wine-growing in the face of the phylloxera outbreak of 1867. Although 'Alexander' has slipped out of commercial cultivation and was perhaps hardly, if ever, grown in Australia, 'Isabella' is still grown here (Kerridge \& Antcliff 1999: 198), though the foxy or blackcurrant taste of the grapes inherited from $V$. labrusca has meant that, lest the vendange be contaminated, it has been illegal since 1934 to plant 'Isabella' and other vinifera-labrusca crosses in France for example (Pinney 1994). 
Because of the disease resistance and disagreeable flavour (to most palates) coming from $V$. labrusca, it is useful to be able to distinguish formally between the cultivars derived from just $V$. vinifera, and those of the original hybrid parentage. In recent bibliographical research to ascertain the earliest name for these $V$. vinifera-V. labrusca crosses (Mabberley 1998: 143), the importance of the publications of the French growers, who introduced the hybrids to Europe in the first decades of the nineteenth century, was emphasized. 'Isabella' for example, was offered (as ' $V$. isabellae', Prince's nursery name of 1822) by Audibert of Tonelle, near Tarascon, in southern France at least as early as 1830 (see Mabberley 1998: 143) and (as 'Isabelle'), by JacquemetBonnefont of Lyon by 1833 (Catalogue et prix-courants: 11, 1833). By examining the French horticultural literature of the 1820s, it has now become possible to pinpoint the earliest botanical name for the first 'American Hybrids' as follows:

Vitis $\times$ alexanderi Prince ex Jacques, J. Soc. Agron. Prat. 1829: 409 (Dec 1829), pro sp.

[Vitis $\times$ alexanderi Prince, Cat. Trees Plants, ed. 21: 27 (1822), pro sp., nom. nud.]

Vitis $\times$ isabellae Jacques [pro sp.] var. alexanderi (Jacques) Jacques, Ann. Fl. Pomone 1834: 302, cum tab. (1834), nom. illeg. ('Isabella' was the basis for the autonymic variety).

Type: France, Neuilly (cultivated; introduced from Prince's Linnaean Botanic Garden, Flushing, New York in 1825), fl. June 1829 \& fr. 1829, H. Jacques s.n. (FI ?, n.v.; apparently not preserved, in which case Jacques's 1834 plate based on that very plant would be a good candidate for a neotype [iconotype]: 'Vitis Isabellae Alexanderi', Jacques, l.c.). This plate is a clear link to Jacques's taxon and in this unusual case an illustration would seem preferable to a modern herbarium specimen, particularly as 'Alexander' seems not to be in general cultivation today. Indeed the grape seems not to be grown at all in Australia or Europe, though material referred to the old cultivar is represented in the grape germplasm collection of the USDA-ARS Plant Genetic Resources Unit of Cornell University, USA (Warren F. Lamboy in litt.).

Vitis $\times$ prolifera Raf., Medic. Fl. 2: 134, t. 100, f. F (1830), pro sp.; Mabb., Paradisus: 94, t. 37, \& 143 (1998), q.v. for discussion of type and further synonymy, syn. nov.

Henri-Antoine Jacques (1782-1866) got his plant from Louis Noisette (1772-1849), who had imported it directly from William Prince at Flushing, New York, in 1825. Jacques gives a full description of the plant he had at first kept in a pot but which flowered and fruited when planted outside at Neuilly in 1829: besides morphological features he includes not only an account of its characteristically 'foxy' berries but also that of its hermaphrodite flowers like those of cultivated forms of $V$. vinifera. Although Jacques calls it 'Vigne d'Alexandrie [i.e. Alexandria]', and Prince had it as 'Alexandrian' before him, Jacques corrected that in 1834 to 'Vigne d'Alexander' as it commemorates John Alexander, gardener to Governor John Penn (1729-1795), William Penn's grandson, following Prince's catalogues' 'Alexander's or Schuylkill muscadel ...' (1823: 31, 1825: 34 [National Agricultural Library, US Department of Agriculture, Beltsville, teste Cheryl Toefield in litt.], 1826: 32), but included it under V. isabellae, a name (unlike $V$. alexanderi) not validly published before that. John Alexander had found it in the hills near the Schuylkill River, hence the other early vernacular name (Hedrick 1908: 160-1).

\section{Conclusion}

Cultivars derived from the Old World grapevine alone are therefore to be written Vitis vinifera 'Cabernet Sauvignon' or V. vinifera 'Purpurea', for example ; those with the hybrid parentage as, for example, Vitis $\times$ alexanderi 'Isabella' or $V . \times$ alexanderi 'Concord'. 


\section{Postscript}

The volume where Vitis $\times$ alexanderi was first published was the successor to the shortlived Journal des Jardins (1828), copies of both of which are held in the Bibliothèque Centrale of the Muséum National d'Histoire Naturelle, Paris, for example, but they are rather little known as yet in Australia (cf. Mabberley 1999); new validly published binomials in both, referring to Australian native plants being grown in Europe in the 1820 s, though not yet in APNI (nor Index Kewensis where $V . \times$ alexanderi is not found either), are:

Boronia caerulata Boitard, J. Jard.: 154 (1828, Rutaceae)

Embothrium acanthifolium Hort. Angl. ex Cels, J. Soc. Agron. Prat. 1829: $345(1829)=$ ? Grevillea acanthifolia A. Cunn. (Proteaceae)

Mimosa lunata Noisette, J. Jard.: 118 (1828) = ?Acacia lunata Lodd. (Leguminosae)

M. prostrata Noisette, l.c., non Lam. (i.e. Neptunia prostrata (Lam.) Baill.) = ? Acacia prostrata Lodd., i.e. A. genistifolia Link

M. semperflorens Noisette, 1.c. = ? Acacia semperflorens Jacques

Petrophile triloba Cels, J. Jard.: 186 (1828) as 'Petrophylla' = ? Isopogon trilobus R.Br. (Proteaceae).

\section{Acknowledgments}

I am most grateful to Sherry Vance of the L.H. Bailey Hortorium at Cornell University, USA, for photocopies of the germane entries from Prince's nursery catalogues and to Cheryl Toefield for details of the USDA holdings of them. Warren F. Lamboy provided information on the grape germplasm holdings at Cornell and both Phillip Kodela and Bruce Maslin kindly helped with the previously unlisted names in Mimosa. Jacques Florence $(\mathrm{P})$ kindly checked some of the French literature for me.

\section{References}

Hedrick, U.P. (1908) The grapes of New York. Annual Report of the New York Agricultural Experiment Station 3(2)

Kerridge, G. \& Antcliff, A. (1999) Wine Grape Varieties. Revised ed. (CSIRO: Collingwood).

Mabberley, D.J. (1998) Paradisus: the Hawaiian Plant Watercolors of Geraldine King Tam (text). (Honolulu Academy of Arts: Honolulu).

Mabberley, D.J. (1999) ‘Robert Brown's' Parisian Podolepis (Compositae). Telopea 8: 297-8.

Pinney, T. (1994) United States (History). Pp. 1003-5 in Robinson, J. (ed.), The Oxford Companion to Wine. (Oxford University Press: Oxford \& New York ).

Scherz, W. \& Zimmermann, J. (1953) Die Kulturrassen der Gattung Vitis. Die Natürlichen Pflanzenfamilien, ed. 2, 20d: 334-371. 
